\title{
Diction and Social Status in Sasak Language
}

\author{
1 Istikhorini Atika \\ 1Mataram University, Mataram, Indonesia \\ istikhoriniatika@gmail.com
}

\begin{tabular}{|c|c|}
\hline Article Info & bstract \\
\hline $\begin{array}{l}\text { Article History } \\
\text { Received: July 12, } 2018 \\
\text { Accepted: September } \\
2018\end{array}$ & \multirow{2}{*}{$\begin{array}{l}\text { This paper aims to discuss varied dictions that emerge towards different } \\
\text { social status in Sasak community. By using purposive sampling technique, } \\
\text { several Sasak speakers who have diverge social status in community were } \\
\text { taken as the sample. Data of this study were gathered through ethnographic } \\
\text { observations and interviews, and then analyzed using ethnography of } \\
\text { communication and analysis of interaction. The research finding showed the } \\
\text { mostly found diction forms of Sasak language are pronominal persona } \\
\text { marking. Sasak speakers tend to use high Sasak (base alus) when speaking } \\
\text { with someone who has honorific title such as menak or hajj. However, if the } \\
\text { relationship is intimate, the Sasak diction will be switched into plain Sasak } \\
\text { (Sasak jamaq) even to those having honorific title. The intimate relation } \\
\text { among family can break the use of high Sasak (base alus), especially for hajj, } \\
\text { but it rarely happens among close friendship. Conversely, the high Sasak } \\
\text { (base alus) or vernacular Sasakized Indonesian is used in order to save face } \\
\text { in the interactions among stranger. }\end{array}$} \\
\hline $\begin{array}{l}\text { Keywords } \\
\text { Diction; Social Status; Sasak; } \\
\text { Ethnography; } \\
\text { Communication; Honorific }\end{array}$ & \\
\hline & \\
\hline
\end{tabular}

\section{INTRODUCTION}

Lombok is not only interesting with its tourism object such as exotics place, art, food, traditional ceremony, etc. however its language and how society uses the language are also interesting. Sasak is local language used by Lombok Island and involved into West Malayo-Polynesian. It saves its own specialties and uniqueness. Understanding Sasak language will be difficult if ones do not have knowledge about all social aspect. Language is not only means of communicating information, but also it establishes and maintains social relationship (Trudgill, 2000: 01). In other words, language can be argued as social tendency in humans' life. In relation to the social tendency above, there is nonlinguistic factor that influence language use, and one of them is social status. The existence of the social status enables to create diversity in language. Each person has different way in uttering his/her language, and the differentiation can be seen while people create diction. Thus, it can be concluded that language and social relationship are linked each others. There is no language without social context, and vice versa. Therefore, a deep understanding and analysis towards those complexities are necessary because the general view of communication in Sasak can only be easier to be recognized while the social aspect above is involved.

Sasak language is imposed by diglossic situation in which while Sasak person say something, it will be followed by different variation of language such as high, middle, and low speech level. It needs to be noticed that the kinds of language variation above are meant as diction in this study. These variations above are influenced by Sasak social statuses which are divided into stratification such as high group status and lower group 
status. Typically, the high social groups have nobility title or engage with high position in government and society's life; meanwhile, lower social group is only luck to connect to the same social upper class. Hence, it can be argued that in Sasak society is nearly impossible to communicate language without indicating into social relationship among speaker and interlocutor in case of social status. Based on the reality above, this study is intended to explain about varied diction in Sasak language that emerges towards different social status in Sasak community.

Moreover, this study is also intended to give contribution for tourism choice in Lombok. Thus it will not be only limited to explore place, art, food, traditional ceremony, and etc. but also to explore language used of Sasak.

\section{METHOD}

This study used quantitative approach with ethnography design. Purposive sampling technique was considered to gain the sample. Further, several people who have diverge social status in community and applied Sasak language were concerned as the sample of this study. Besides that, to obtain the data collection, ethnography observation and interview is applied. And by using ethnography communication and analysis interaction, the data was analyzed.

\section{RESULT}

According to Khalik (2013), the pattern of Sasak code choice used in dialogue consist of four pattern such as Symmetrical Pattern, Asymmetrical Pattern, Pseudosymmetrical Pattern, and Stratified pattern. Through the pattern above, this study is intended to explain diction that appears in Sasak social status. However, due to researcher limitation, in this study only Symmetrical Pattern and Asymmetrical Pattern were obtained. When both speaker and interlocutor want to be equal in interaction, Symmetrical Pattern of Sasak is used. This pattern contains two type; low and high symmetric code(s). Nevertheless, based on the study conducted towards dialogue record in phone call, low symmetric code(s) pattern is found such as; rude Sasak (Sasak kasar) used symmetrically by a Sasak to his intimate friend to show intimacy, and plain Sasak (Sasak jamaq) used symmetrically to show solidarity in general friendship relation or in any casual interaction.

\section{Dialogue 1: interaction among general friendship. \\ ZD: Mecoom..}

KY: di, e...inget-m pire DR Rus tie, nde-m tao?

ZD: aneh, lupa-k

KY: aok...suru-n tecekan uni-n, laguan nden jau anu-n copyia-n, nane coba anu DR-n, ampo cobak checkan.

ZD: o...wah-n kenemenu?

KY: aok..coba anuan. Mbe tao-m ni, di?

ZD: leq Ranjok...hi..hi..

By uttering the words such as clitic-m = kamu (you) and aok (yes), the dialogue above was indicated as the plain Sasak (Sasak jamaq). It is frequently used to communicate with friend. Besides, the plain Sasak (Sasak jamaq) above enable to be rude Sasak (Sasak kasar) while it is entered by crude word. For example, "mate-m" (with stressing intonation), the word mean is 'eye', however it is not meant to indicate the part of body, it is mentioned to show the situation in which person is very annoyed towards someone's behavior. Another example, "nden tao jaga tunggak ela- $n$ " is meant 
as someone cannot keep their mouth from uttering crude speech. These examples are included in rude Sasak (Sasak kasar) and they are frequently uttering among intimate friend. Additionally, the example such as "mate-m" is also often uttered by parents to child to show their anger or annoyance.

Meanwhile, Asymmetrical Pattern realized when speaker and interlocutor were not equal in terms of social status, age and education. High Sasak (Sasak alus) is used asymmetrically by a subordinate to his boss or by a poor man to a rich man, a common people or a poor man to a very rich man, a slave/worker to a noble man/master (usually landlord), students to his teacher in non-classroom context, a wife to her husband, a child to his parents, and a younger man to an older one. However, the results of Asymmetrical Pattern of Sasak language in this study are different with Khalik's result above. This study was conducted through phone call recording towards several participants who have noble title, position in government office, and age diversity.

\section{Dialogue 2: interaction between BKN and Samsat employee}

Samsat employee : Waalaikumussalam, makam telang, Dan? Makam ndek wah peta STNK-m

BKN employee : ndek man mau, tiang kurang sehat.

Samsat employee: ndek wah-m tame?

BKN employee :lemak wah tiang bait, sampun wah tiang terima sms.

From the dialogue above, the BKN employee use high Sasak (Sasak alus) to speak with Samsat employee. They have same position as the employee in government office, yet due to the age diversity among them, the BKN employee as the younger one tends to use high Sasak (Sasak alus) while uttering language. The words such as tiang and sampun indicates the high Sasak (Sasak alus)

Dialogue 3: interaction between someone who have honorific title that is Hajj and Samsat employee.

Samsat employee : Assalamulaikum, Ji!

Haji $\boldsymbol{U}$ : Waalaikumussalam Wr. Wb. Mbe tao-d

Samsat employee : niki maseh leq Pemenang.

Haji $\boldsymbol{U}:$ o.....h, anu salam pak ustaz ongkat-n, ndek arak pengajian lemak ngkah lebaran topat basen, uin bada tiang leq Jum'at nike.

Samsat employee : berarti ndek narak lemak leq niki.

Haji $\boldsymbol{U}$ : nggih ndek arak lemak

Samsat employee : o.....

Haji $\boldsymbol{U}$ : lemak ngkah lebaran topat, salam leq batur-batur nike.

Samsat employee : makasi wan.

Haji U: nggeh sama-sama

Samsat employee : sehat?

Haji $\boldsymbol{U}$ : Allhamdulillah

Samsat employee : nggeh-nggeh silaq.

Haji $\boldsymbol{U}$ : Salamualaikum Wr. Wb.

The dialogue above indicates speaker and interlocutor always use high Sasak (Sasak alus) in every word they uttered. Samsat employee use high Sasak (base alus) to respect his/her interlocutor honorific title as the Hajj. The high Sasak (Sasak alus) words are demonstrated from the words such as niki (this), nike (that), nggeh (yes), and silaq (let's). The exception to use high Sasak (base alus) is happen when having intimate relationship in family. This is usually happening because previously in family, especially 
towards child, someone does not use high Sasak (base alus). Hence after the Hajj title is given, child is not used to utter high Sasak (base alus), instead he/she still use pain Sasak (Sasak jamaq).

Dialogue 4: interaction among the head of cooperation (having noble title as menak) with Samsat employee.

Samsat employee: Halo

The head of cooperation: Halo, Assalamekom pak Ki.

Samsat employee: Waalaikumussalam, brembe mik?

The head of cooperation: Side masih di Kantor niki?

Samsat employee: masih, napi arak?

The head of cooperation: tiang..?, halo pak Ki.

Samsat employee: enggeh, berembe-berembe?

The head of cooperation: side masih di kantor?

Samsat employee: masih..

The head of cooperation: o...pak Ki, bisa tiang minta tolong di checkan, berapa ini dia bayar niki.

Samsat employee: iya..iya..

The head of cooperation: DR $4280 \mathrm{HU}$

Samsat employee: bentar dulu bentar, sebentar saya buka dulu.

The head of cooperation: Ok..makasi meton.

In this dialogue, the head of cooperation use vernacular Sasakized Indonesian (Indonesia alus) to speak with Samsat employee. Formerly, Samsat employee uses high Sasak (Sasak alus), then code switch to vernacular Sasakized Indonesian (Indonesia alus). He/she use high Sasak (Sasak alus) to show his/her respect toward the head of cooperation's noble title as 'menak'. The vernacular Sasakized Indonesian (Indonesia alus) is used by them due to their position in a government official. The words such as niki (this), side (you), napi arak (what), tiang (I), and enggeh (yes) are argued as the high Sasak (Sasak alus) index in this study. Several words in Indonesia is uttered, yet the grammar is in the Sasak pattern. Besides the reason of code switch to Indonesian language as the effect of position in a government official, usually person switches into Indonesian language to hinder wrongness while speak with someone who has high social status.

Dialogue 5: interaction among husband and wife.

KY : e....kamu ngebel baru?

MN: e...aku leq langan ni, wah-k lalo belangar

$\boldsymbol{K} Y$ : jok mbe?

MN : kan baru aku bell-d, haji medan ye mbilinan.

KY : o...innalillah, Dasan Agong?

Comparing this dialogue with Khalik's research, the kinds of Sasak language pattern used by husband and wife is plain Sasak (Sasak jamaq). These are indicated from the words such as lalo (go), kamu/clitic-d = side (you--side is more polite than kamu), and clitic- $k=a k u$ (I). These words above have equivalent in high Sasak (Sasak alus) such as lumbar (go), pelungguh/side (you), and tiang (I).

Dialogue 6: interaction among a child to his/her parents.

K: halo...

KY: Halo...assalamualaikum 
K: Waalaikumussalam, ape pak?

KY: mbe mak-m?

K: ye, lalo belanje.

KY: bareh badaan aok, lemak tuak sahdi jan lite senen bait kerupek nu.

K: sai?

KY: tuak Sahdi-m.

K: o...aok

KY: badak ma-m aok!

Similar with the dialogue among husband and wife above, in this case, plain Sasak (Sasak jamaq) is applied. The words such as ape (what), clitic- $m=$ kamu (you), lalo (go), and aok (yes) are indicated as the plain Sasak (Sasak jamaq) which have equivalent in high Sasak (Sasak alus) such as napi, pelungguh, lumbar, and nggih. Additionally, the word 'side' is the polite form of 'kamu' often used in dialogue among husband and wife, and a child and his/her parents to declare their sign of respect.

The dialogue 5 and 6 is categorized as the intimate relationship among family, hence they tends to use plain Sasak (Sasak jamaq). Even though, in the family, they have honorific title, due to its intimacy, the role of high Sasak (Sasak alus) is broken. These phenomena also appear among close relationship among friend, especially for noble title.

Dialogue 7: interaction among menak and jajakarang

Bapak: Waalaikumussalam, maaf Bq nde- $k$ wah mau angkat telpo-m

Bq: eni, jak bada-m bu R. kan mbilinan.

Bapak: innalillahi wa innalillahirojiun

Bq: tao-m ye?

Bapak: ndek...

Bq: no kan...! ane anu datang $E, D, M$ and $M R$.

Bapak: ndek nara..

Bq: onen betalet jam sepulu pas onek ketelpo-m nu. Unin mbilinan

Bapak: wahn jarin betalet?

Bq: onek angka jam sepulu $n$.

Bapak: iye sakit?

Bq: aok, lagu ongkat W. Iye nden sakit, ye mule wah menu.

Bapak: aku ndek buka hp-ng, aku leq masjid jam siwa nu, soaln ara acare.

The words such as clitic-k, $m$ means aku (I) and kamu (you), aok (yes), and ongkat (speech) indicate they are speak plain Sasak (Sasak Jamaq). Based on the interview, they are schoolmate that mean they are intimate friends and to show solidarity, plain Sasak (Sasak Jamaq) is used. Additionally, based on the interview towards, family whose has honorific title such as Datuk, they do not speak with high Sasak (Sasak alus) anymore. These phenomena may be happen due to their intimacy to their family or there is change status.

\section{CONCLUTION}

In brief, the conclusions that enable to be taken are the diction forms of Sasak language pattern are mostly found in the form pronominal persona marking. Sasak Person tends to use high Sasak (base alus) when speak with someone who has honorific title such as menak or hajj. However, if the relationship is intimate, the Sasak diction choice will be switched into pain Sasak (Sasak jamaq) even though having honorific title. Especially for 
hajj, the intimate relation among family can break the use of high Sasak (base alus), and seldom among close friendship. Conversely if there is interaction among stranger, in order to save face, the high Sasak (base alus) or vernacular Sasakized Indonesian is used.

\section{REFERENCE}

[1] Khalik, L.A. 2013. International Journal on Education. The Patterns of Sasak Code Choice, 1 (1): 37-47.

[2] Meyerhoff, M. 2006. Introducing Sociolinguistics. New York: Routledge.

[3] Trudgill, P. 2000. Sociolinguistic: an Introduction to language and society. New York: Penguin Book.

[4] Setiawan, I. 2015. International Journal of Linguistic, Literature and Culture. Social Dialect Variation in Sasak Monolingual Society: A Lingual Critical Study.1 (1): 1-14.

[5] Keraf, G. 2006. Diksi dan Gaya Bahasa. Jakarta: PT Gramedia Pustaka Utama.

[6] van Dijk, T. A. 2008. Discourse and Context: A Sociocognitive Approach. Cambridge: Cambridge University Press.

[7] Zuhdi, M.H. 2012. Praktik Merariq: Wajah Sosial Orang Sasak. Mataram: Lembaga Pengkajian-Publikasi Islam dan Masyarakat. 